\title{
ELF 帯電磁波を用いた地震前兆現象の観測*
}

\author{
太田健次 ${ }^{* *}$, 渡辺伸夫**, 早川正士*** \\ **中部大学工学部電子情報工学科 $* * *$ 電気通信大学工学部電子工学科 \\ * Observation of Precursory Phenomena on Earthquake \\ using ELF Electromagnetic Waves \\ **Kenji OHTA, **Nobuo WATANABE \\ Department of Electronics and Information Engineering, Chubu University, \\ Kasugai, Aichi 487-8501 Japan \\ *** Masashi HAYAKAWA
}

Department of Electronic Engineering, The University of Electro-Communications, Chofu, Tokyo 182-8585 Japan

\begin{abstract}
There are two kinds of method to estimate precursory signature of earthquakes by means of electromagnetic waves. The direct method is measuring emissions from the ground surface of the epicenter. An example of this method is ULF/ELF electromagnetic emission because its propagation loss in the ground is very low. Another method can be called "indirect method", by measuring the change in amplitude and/or phase of VLF/LF subionospheric propagation due to the change in the ionosphere disturbed by the energy from the epicenter. VLF/VHF signals are used in order to study the anomaly in their propagation. These two methods (direct and indirect) are very complementary to each other. We have carried out our observation of ELF electromagnetic waves below $50 \mathrm{~Hz}$ at Nakatsugawa in Japan (Geographic lat. $35.4^{\circ} \mathrm{N}$, long. $137.5^{\circ}$ E in Gifu Prefecture near the foot of Mt. Ena). We have analyzed ELF electromagnetic waves (emissions) by means of the direct method, and also the modification of the ionosphere using Schumann resonance (as indirect method) for the Taiwan Earthquakes in 1999. It is found that we can detect the precursory signature of Taiwan earthquakes by both of these methods.
\end{abstract}

Keywords: Precursor of earthquake, Direction finding of ELF wave, Schumann resonance

\section{1.はじめに}

電磁波を用いた地震前兆現象の観測には大別して $2 つ$ 手法があるように考えられる. その 1 つ，岩盤に対 する圧力変動によって岩石の破壊や荷電粒子の移動による誘導電流等によって震央の極めて近傍から発生する電 磁波の一部を地表面で直接観測 (以後, 直接観測法と呼ぶ) するもので, 深い地中を伝搬するため, 一般に ULF/ELF 帯電磁波の観測が有望とされている[1]. 他の 1 つは, 地中から発生する超低周波の電磁波や荷電粒子が地表面か ら電離層に放出され，その結果として震央上空の電離層が擾乱し、電離層で反射される送信局電波に強度/位相の 変動を与えるもので, 地震の前兆を電離層の擾乱で間接的に知る（以後, 間接観測法と呼ぶ）ものである [2]. 一 般に送信局電波は電離層で反射する VLF/VHF 带の電波が用いられている，いずれの方式であっても，本震の前後 に変化が検出されることになるが特に本震の前に現れる電磁変動をここでは電磁波による地震前兆現象と呼ぶこ とにする.

我々は直接観測法を 1998 年より自然電磁環境の比較的良好な，岐阜県中津川市の恵那山麓のある中津川観測所 (地理緯度 $35.4^{\circ} \mathrm{N}$, 地理経度 $137.5^{\circ} \mathrm{E}$ ) で ELF 帯電磁波 $(50 \mathrm{~Hz}$ 以下)の予備観測を開始し, 観測機器の改良を行 っている [3]. また, 間接観測法では, 1997 年より愛知県春日井市の中部大学 $\left(35.2^{\circ} \mathrm{N}, 137.0^{\circ} \mathrm{E}\right)$ にて VLF 帯 電磁波 $(10 \mathrm{kHz} \sim 40 \mathrm{kHz})$ の観測を行っている [4].これら.2つの観測法は互いに補閒の関係にあるが対象とする周波 数が大きく異なるため, 装置も解析法も異なる.このため, 異なる 2 つ観測法を維持することは観测にも解析 にも経済的, 時間的な制約がある.そこで, 電離層をモニタするVLF 帯電磁波を ELF 帯電磁波であるシューマン 共振の観測で置き換えることを試みている.ここでは, 1999 年 9 月 21 日 2 時 47 分 (日本時閒, 以後時刻はすべて JST) 台湾北西部集集 (Chi-Chi) で発生したマグニチュード 7.6 (以後, M=7.6 と記す) の地震 [5]の前兆現象につい て，直接観測法と間接観測法で解析したのでその結果について報告する。 


\section{ELF 帯電磁波の観測}

ELF 帯電磁波の観測システムを図 1 に示す. 基本的にはインダクションコイルを用いた ELF 帯の磁界 3 成分 (Bx, By, Bz) を $30 \mathrm{~Hz}$ の LPF を含むプリアンプ（利得 $66 \mathrm{~dB}$ ) に導く．その後， $100 \mathrm{~Hz}$ のサンプリング周波数で A/D 変換した後，6時間ごとにハードディスクに保存する.このファイルは 1 日で 4 ファイルとなり，ファイルネーム の先頭に観測日を, 末尾にファイル番号 0 (00 時 00 分〜 05 時 55 分), 1 (06:00〜 11:55), 2 (12:00〜17:55), 3 (18:00 〜23:55) を自動的に付記し, 日時を区別している.ディスクに保存する時間は観測が中断されるが 6 時間ごとに 僅か 5 分であるため無視している.このデータは定期的に回収され, ディスクを交換し，観測を続行している. 信号解析はデータ長を 1024 にした FFT 解析を用い, サンプリング周波数が $100 \mathrm{~Hz}$ であるため, 時閒分解能 $10.24 \mathrm{~s}$, 周波数分解能 $0.098 \mathrm{~Hz}$ で $0 \mathrm{~Hz}$ から $50 \mathrm{~Hz}$ までの周波数解析が可能で, 磁界 3 成分の振幅と位相差が得られる.

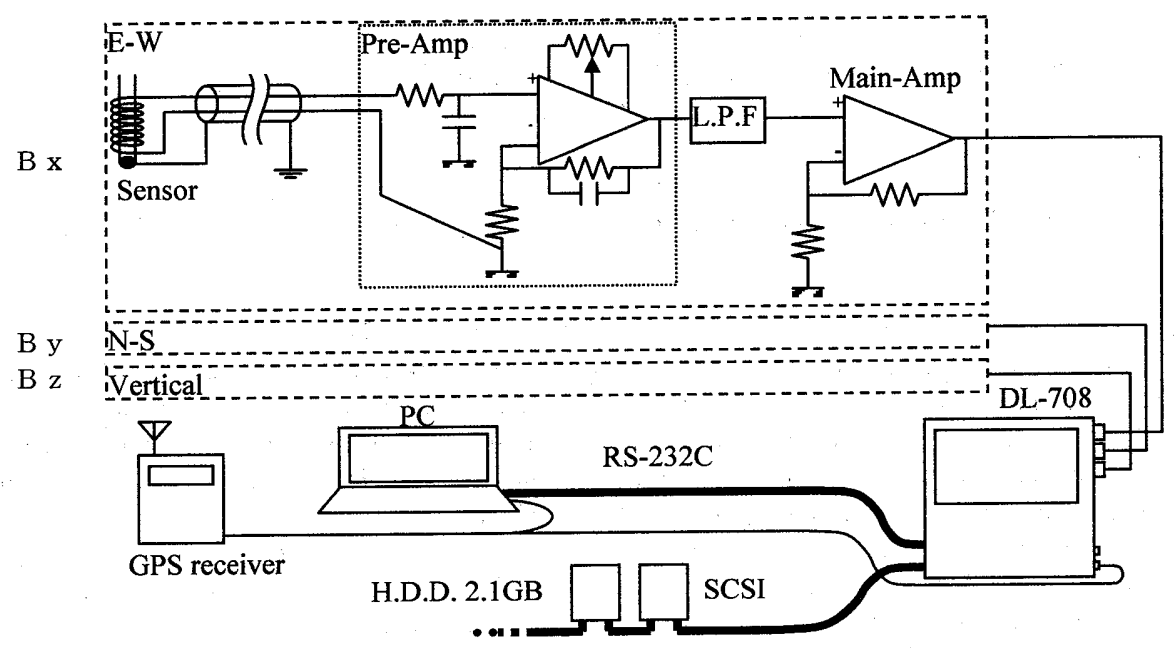

Fig. 1. The observation system of electromagnetic wave in ELF.

\section{3. 台湾地震における直接観測法のデータ解析}

図 2 は 1999 年 9 月 1 日より 9 月 30 日までの各ファイルにおける $18 \mathrm{~Hz}$ の平均水平磁界強度 $\left\{\left(\mathrm{Bx}^{2}+\mathrm{By}^{2}\right)^{1 / 2}\right\}$ のレベル変動を示したものである.日付はファイル 0 の直下に示す. 図において，9月 15 日（ファイル0，00:00

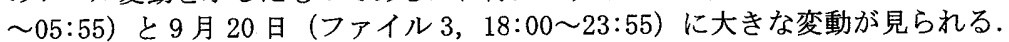

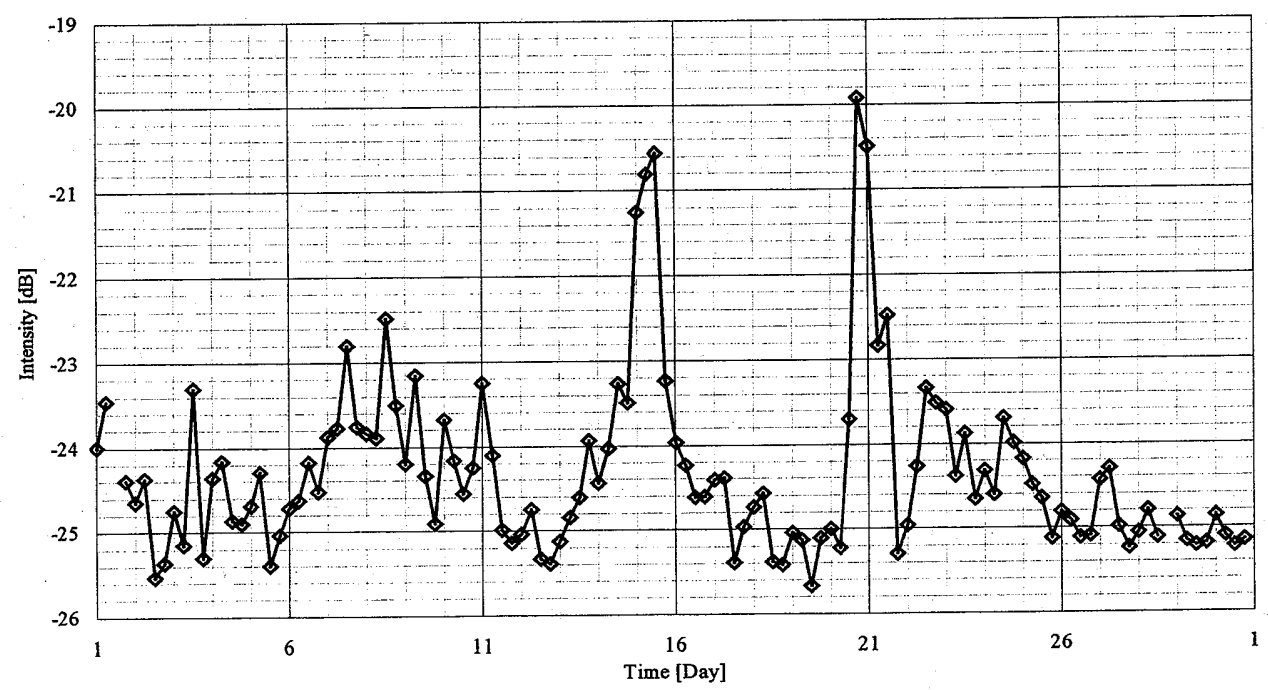

Fig. 2. Intensity level of $\left\{\left(\mathrm{Bx}^{2}+\mathrm{By}^{2}\right)^{1 / 2}\right\}$ in $18 \mathrm{~Hz}$ from September 1 to 30 in 1999 . 
当然ながら, VLF 以下の周波数帯域においては電磁波強度の変動に最も大きな影響を与えるものは雷放電である. 15 日ピークを示すファイル $2(12: 00 \sim 17: 55)$ においては，中津川観測所より北西および北東方向に雷雲が広く 分布していたが夏期の雷放電活動としては穏やかであり，図 2 に見られる 15 日（12:00～17:55）における磁界強 度のピークは雷放電によるものではない。この急激な上昇については第 4 節で明らかにする.

しかし，図 2 の 20 日ファイル 3（18:00～23:55）における磁界強度のピークは，雷放電活動とよく符合してい た. 図 3 に 9 月 20 日ファイル $0 \sim 3$ における $18 \mathrm{~Hz}$ の細かな磁界強度 $\left\{\left(\mathrm{Bx}^{2}+\mathrm{By}^{2}\right)^{1 / 2}\right\}$ 変化を示す. 20 日は 00 時より 12 時頃までは雷放電活動はほとんど発生していない. 雷放電活動は 12 時 30 分頃から活発になり，中津川 観測所より北西方向の岐阜県郡上八幡町の山間部では落雷を伴う記録的な豪雨となり, 18 時から 21 時には岐阜県 美濃地方, 飛騨地方, 長野県御㒛地方の広い範囲で落雷が発生した. 21 時から 23 時には再び岐阜県郡上八橎町か ら美濃加茂市の山間部で活発な雷放電活動があった。しかし, その後雷雲は岐阜県東濃地方, 長野県御岦地方, 長野県駒ヶ岳地方に分散し，次第に終息した.

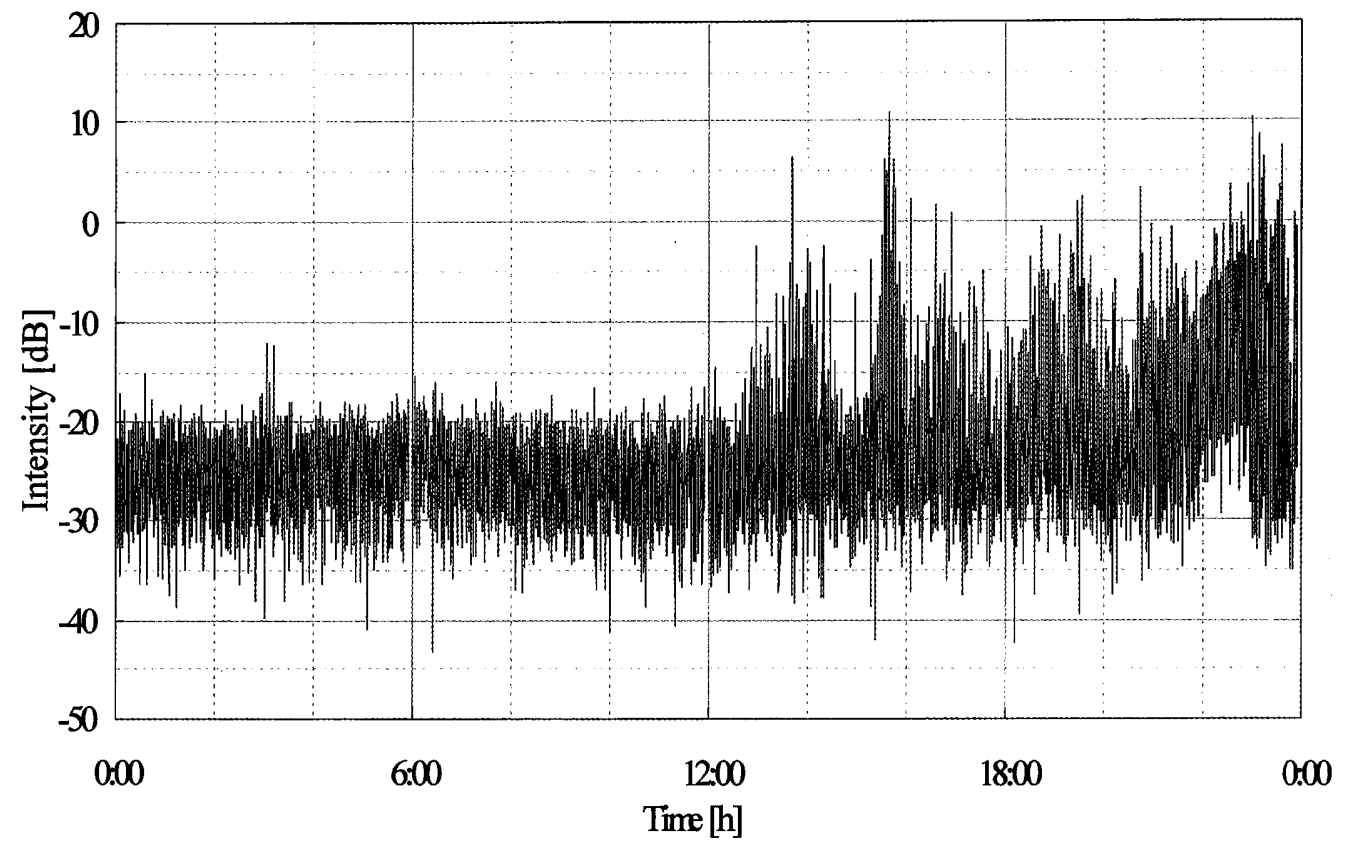

Fig. 3. A change of noise level in $18 \mathrm{~Hz}$ on September 20.

図 3 に示す細かな磁界強度の変化はこれらの雷放電活動をよく示している. 00 時より 12 時における平均雑音の レベルは概ね-25dB で極めて安定している. しかし，12 時 30 分以降は一変し，激しく変動している. 特に 21 時 30 分から 23 時では磁界強度のベースが時間の経過と共に $5 \mathrm{~dB}$ から $10 \mathrm{~dB}$ の急激な上昇がみられる。このような急 激なベースの上昇は観測期間中で最大なものである.

図 4 にこの磁界強度のベース変動を詳しく検討するため, 周波数解析のソナグラム（Sonogram）を示す.

図 4 は 9 月 20 日 18:00より 23:55（ファイル 3) における周波数解析である. 横軸はファイル 3 の時間を示し, 時間分解能は $10.24 \mathrm{~s}$ である. また，縦軸は $0 \mathrm{~Hz}$ から $50 \mathrm{~Hz}$ の周波数を示し，周波数分解能は $0.098 \mathrm{~Hz}$ である. そ して, 磁界強度 $(\mathrm{dB})$ を色別で示している. 21 時 30 分よりパルス性雑音と背景雑音の上昇が見られ 23 時以降急激 に減少しているのが容易に分かる.しかし，雷放電活動によるパルス性雑音のみでは図 3 に示す磁界強度のべー ス部分が $5 \mathrm{~dB}$ から $10 \mathrm{~dB}$ も上昇することは解釈できない. なぜなら，21 時 30 分以前にも激しい雷放電活動が発生 しているがベース部分の急激な上昇はほとんど見られない，かつまた，図 3 でベース部分の急激な上昇が見られ る時間帯ではパルス性雑音によるレベル変動は他の時間帯ほどには強く現れていない.このため，図 3 に示す 21 時 30 分から 23 時における磁界強度のベース部分の上昇はこの時間帯における雷放電活動でなく背景雑音が大き く影響しているものと強く推定できる，そして，ソナグラムよりこの背景雑音は極めて低い周波数から $50 \mathrm{~Hz} に ま$ で広く分布している.ここでは代表值として $18 \mathrm{~Hz}$ を選定し，磁界成分の位相特性とその到来方位を解析する.

この背景雑音を解明するため，21 時 30 分から 23 時における $18 \mathrm{~Hz}$ での Bx と By の位相差を図 5 (a)に，その到 来方位を図 $5(b)$ に示す. 


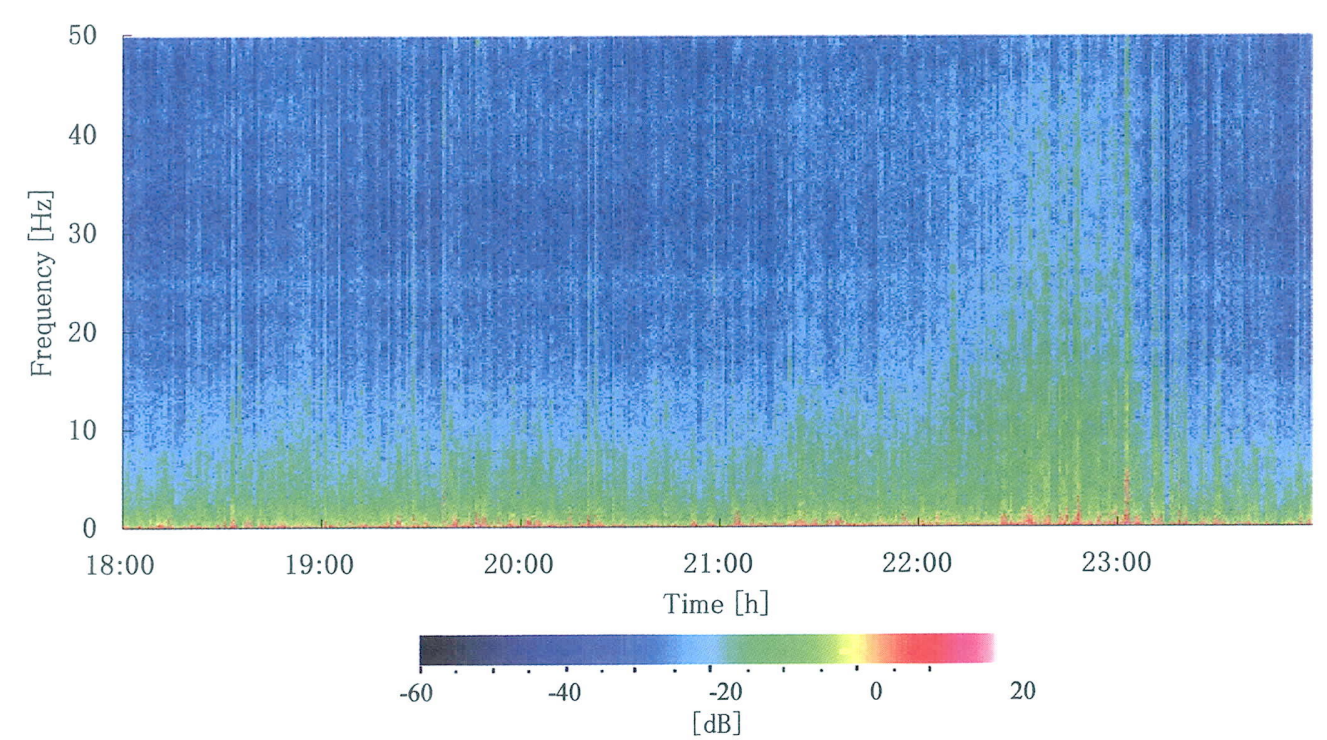

Fig. 4. An example of Sonogram (September 20).

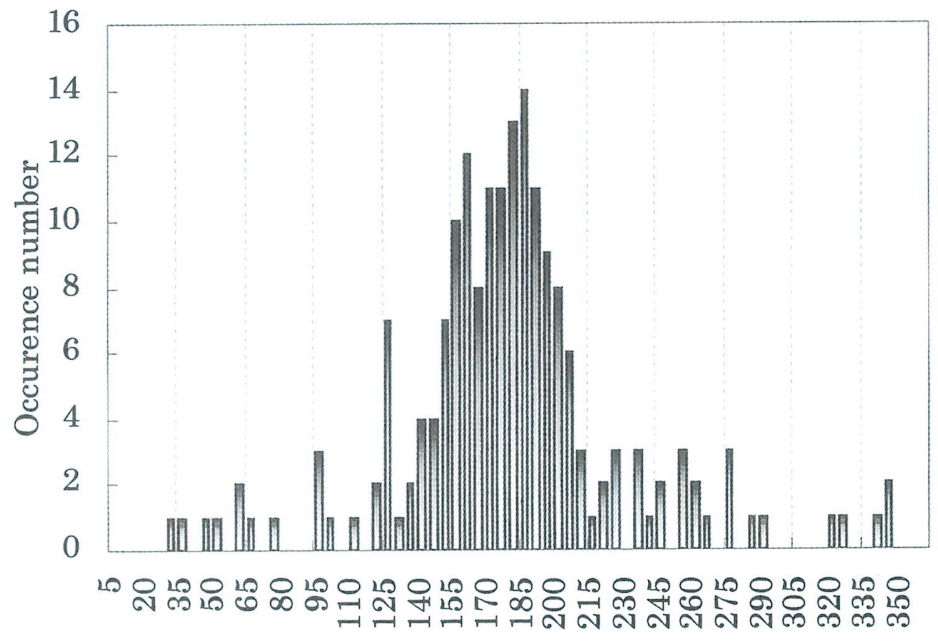

[deg]

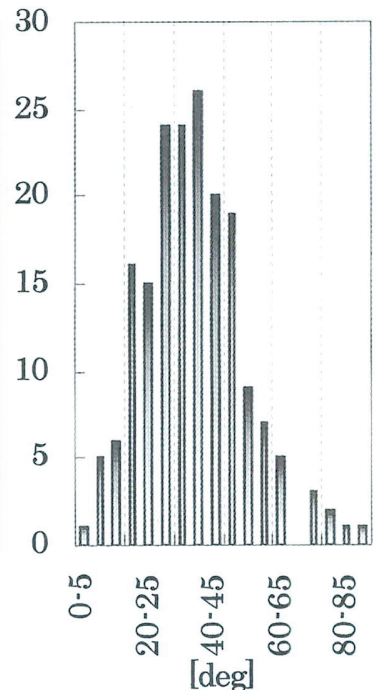

(b) Azimuthal angle.

(a) Phase difference between $B_{x}$ and $B_{y}$.

Fig. 5. Azimuthal angle and phase difference of electromagnetic wave in ELF.

図 5(a)において，位相差の中央值は概ね $180^{\circ}$ であることは明らかである。よって，背景雑音は直線偏波で到 来していると考えられる. ULF/ELF 帯電磁波のように極めて低い周波数における到来方位の測定法は確立されてい ないが，観測された背景雑音が概ね直線偏波と考えられることより，ゴニオメータ法による到来方位測定 [6]を試 みた。図 $5(\mathrm{~b})$ はゴニオメータ法による到来方位測定を示す。なお，角度は第 1 象限で東より北方向に角度を測定 した. 21 時 30 分から 23 時に中津川観測所に到来した背景雑音は概ね $30^{\circ}$ から $40^{\circ}$ に中央值がある. ゴニオメー 夕法では $180^{\circ}$ の不確定さが存在するが，既に記したように 21 時 30 分から 23 時での時間帯においては雷放電活 動が観測所の北西で発生していること，観測点より見て第 1 象限に遠距離伝搬する波源が存在しないことより， ここでは第 3 象限からの到来として取り扱う。この仮定に基づくと, 異常な背景雑音の上昇は第 3 象限の西より 南へ概ね $30^{\circ}$ から $40^{\circ}$ で遠方より中津川観測所へ到来したことになる.

重要なことは, この背景雑音発生後の 21 日未明 02 時 47 分に M=7.6の台湾地震が発生していることである. そ して, 中津川観測所から見て台湾は第 3 象限の西より南へ $35^{\circ}$ の方位にある.つまり，この背景雑音の上昇は台 湾で発生しているもので, 21 日未明 02 時 47 分に発生した M=7.6 の台湾地震の前兆現象と強く推定される. 
なおここの傾向は $50 \mathrm{~Hz}$ 以下の他の周波数帯域においても求められた。直線偏波で到来方位が $30^{\circ}$ から $40^{\circ}$ の 背景雑音は台湾地震の本震, 余震の発生している 21 日 02 時から 09 時においても観測されたことを付記する. ま た、この時間帯における背景雑音の上昇は他の研究者によっても報告されている $[7]$.

\section{4. 台湾地震における間接観测法のデータ解析}

シューマン (Schumann) 共振は完全導体と見なせる大地と電離層間を伝搬する ELF 帯電磁波の球殼内空洞共振で, その源は雷放電である [8]. 共振周波数は概ね $8 \mathrm{~Hz}$ の基本波(1 次モード波 : 以後 Sch1 と略記する) とその高調波 (14Hzの 2 次モード波: Sch2, $20 \mathrm{~Hz}$ の 3 次モード波: Sch3, $26 \mathrm{~Hz}$ の 4 次モード波: Sch4，…)で構成される. 一 般に各モード波の周波数は伝搬する状況 (地球磁界に対する角度, 陸／海, 昼／夜)により概ね土0. $2 \mathrm{~Hz}$ 程度異なり [9], 各モード間の強度は雷放電発生から観測地点までの距離, 雷放電の周波数成分に依存するとされている.

地震の前兆現象として震央上空の電離層が擾乱されることはすでに報告されている [2]. 我々も春日井-NWC（才 ーストラリア）間の VLF 局電波（19.8kHz）［10]や春日井-福島間の標準電波 JG2AS 局（40kHz）[11]を用いて地震 前兆現象の観測を行っている. その解析結果では送信点と受信点の伝搬経路上（80 km 以内）で発生する比較的大 きな地震 ( $M=5$ 以上) では強度/位相に変動が現れることを検出している，そこで，大地一電離層間を伝搬するシュ 一マン共振においても地震前兆現象が観測されるものと考え解析を行った. ここでは, 前節で対象とした 1999 年 9 月の台湾地震で観測されたシューマン共振の異常励起に着目した間接観測法による地震前兆現象についてのみ 報告する.

通常, 中津川で観測されるシューマン共振はSch1 と Sch2 が検出される程度で, Sch3 と Sch4 は次第に雑音に埋 もれほとんど観測されない.しかし，極めて特殊な例を図 6 に示す.

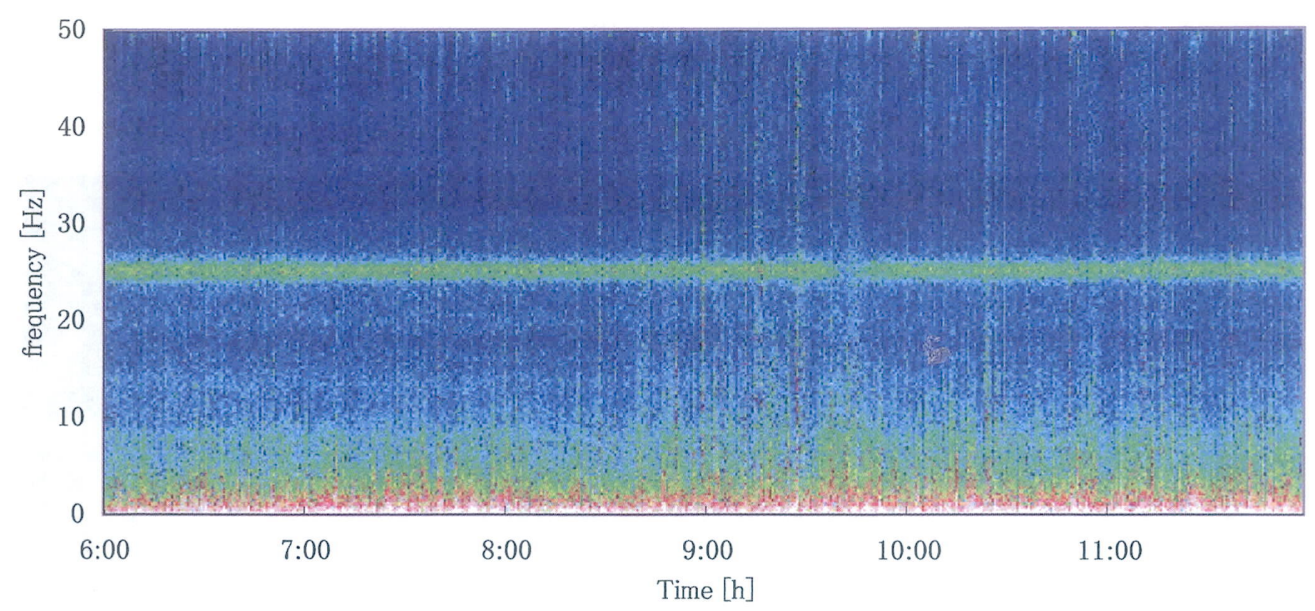

Fig. 6. Sonogram (magnetic field NS (By)) of file 1 on September 15 in 1999.

図 6 は 1999 年 9 月 15 日 6 時 00 分より 11 時 55 分 (ファイル 1) の時間帯における磁界 NS 成分 (By)のソナグラ ムである. 明らかにシューマン共振の異常励起を示すもので, Sch1 から Sch3 はほとんど背景雑音に埋もれている が，Sch4のみが異常に励起されていることが分かる。この観測時期は，増幅部にあるフィルタの設定が十分では なくエリアシングのため $25 \mathrm{~Hz}$ を対称とし，低域の信号が高域に現れている。また，パルス性雑音が多いことが特 徴的である。これは，観測点が夏期に当たり観測点近傍で雷放電活動が活発であることに起因している。パルス 性雑音とSch4 の励起とは相関が見られずSch4の励起が安定していることより，図 6 に見られるパルス性雑音は シューマン共振を生成している雷放電とは関係のない観測点近傍の雷放電活動であるといえる.

図 6 に示す時閒帯での, Sch4の中心周波数とその到来方位を表 1 に示す.

Table 1. Center frequency and arrival direction of Sch4.

\begin{tabular}{|c|c|c|c|}
\hline 磁界 NS 成分(By) & $\mathrm{Sch} 4$ & 磁界 $\mathrm{EW}$ 成分 $(\mathrm{Bx})$ & $\mathrm{Sch} 4$ \\
\hline 中心周波数 & $25.29 \mathrm{~Hz}$ & 中心周波数 & $26.37 \mathrm{~Hz}$ \\
\hline 到来方位の中心角度 & $36^{\circ}$ & 到来方位の中心角度 & $19^{\circ}$ \\
\hline
\end{tabular}


注目すべき点は Sch4 の中心周波数で磁界 NS 成分 (By) が通常の共振周波数より低くなっていることである.シ ユーマンの共振周波数は伝搬する状況により通常 $\pm 0.2 \mathrm{~Hz}$ 程度異なることは既に述べた. しかし, 表 1 に示す磁界 $\mathrm{EW}$ 成分 $(\mathrm{Bx})$ はほぼ正常值であるが, 磁界 NS 成分 (By)の共振周波数は $1 \mathrm{~Hz}$ 程度低くなっている.

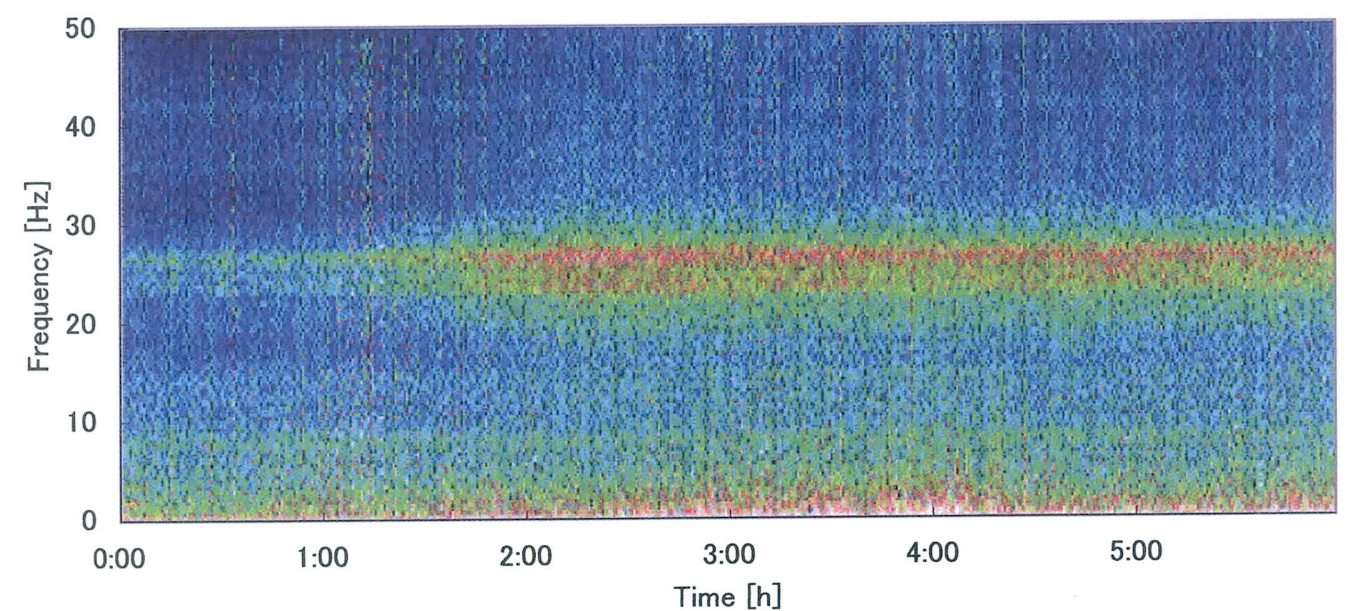

Fig. 7. Sonogram (magnetic field EW (Bx)) of file 0 on September 15 in 1999.

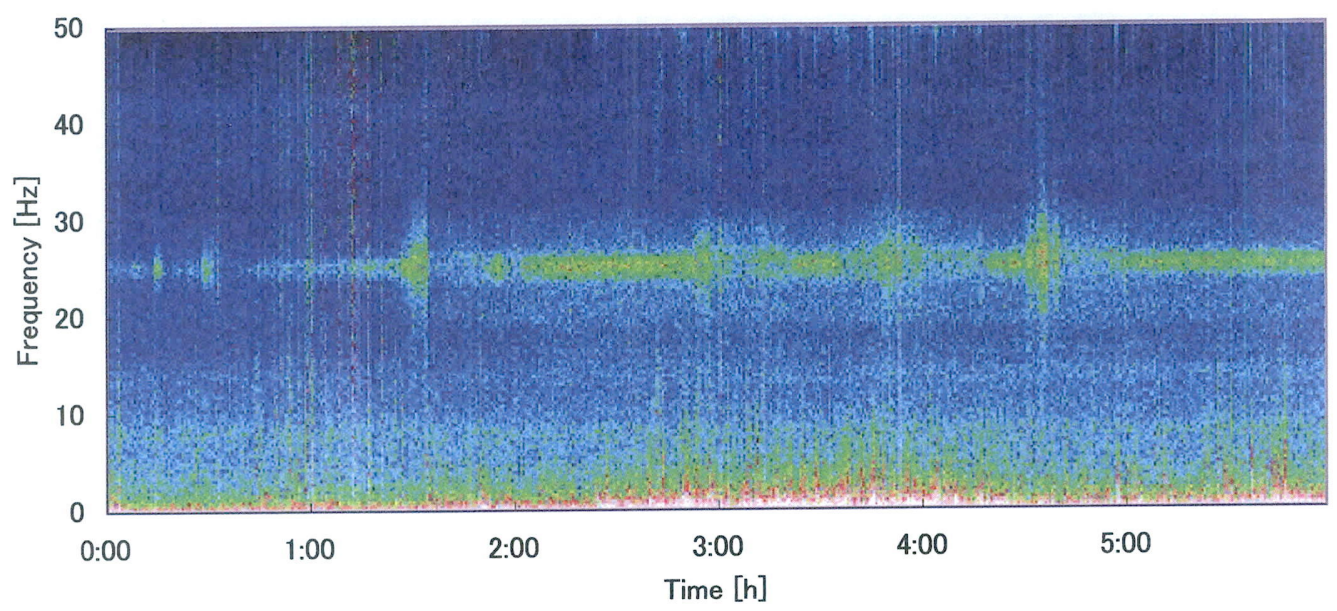

Fig. 8. Sonogram (magnetic field NS (By)) of file 0 on September 15 in 1999.

図 7 と図 8 はそれぞれ 9 月 15 日ファイル 0 における磁界 EW 成分 (Bx) と磁界 NS 成分 (By) のソナグラムで図 6 の 前 6 時間のシューマン共振 (Sch4) を示すものである. 図 7 と図 8 より, 異なる周波数のシューマン共振は同時に 励起されており，単一場所で発生した雷放電によるシューマン共振の励起であることを示している．図 8 の Sch4 に注目寸ると，所々パルス性雑音で励起状態が変動していることが明らかである．励起に変動を与えているパル ス性雑音は数例で，その他のパルス性雑音は図 6 と同様にシューマン共振には全く影響を与えていない。このこ とより, 励起に変動を与えているパルス性雑音と変動を与えないパルス性雑音とは全く異なるものであることは 明らかである。つまり，励起に変動を与えないパルス性雑音は図 6 と同様に中津川観測所の近傍で発生している 雷放電活動によるものと考えられる。 また, このシューマン共振の励起が図 2 における 9 月 15 日の急激な上昇の 原因となっていることはこのソナグラムから明らかである.

ここで, 励起に変動を与えているパルス性雑音の到来方位を求めた. ゴニオメータ法によるこのパルス性雑音 の到来方位は何れも周波数全体としては $35^{\circ}$ にピークが存在する.つまり, 中津川観測所から見て $35^{\circ}$ の方向か 
ら到来していることになる。この時間帯では第 1 象限に雷放電活動がないため，第 3 象限より到来しているもの と考えられる.よって，中津川で観測されたシューマン共振の励起に影響を与えているパルス性雑音は，中津川 観測所で西から南へ $35^{\circ}$ の方位で到来している.この角度は表 1 シューマン共振周波数 Sch 4 の $25.29 \mathrm{~Hz}$ の方位角 と概ね同じである。

これらの解析結果より地震の前兆現象と考えられるシューマン共振の励起には以下に示す特徴がある. (1)シュ 一マン共振の励起は $\mathrm{Bx}$ と By では通常の場合士 $0.2 \mathrm{~Hz}$ の数倍異なる. (2)異なる 2 つの周波数のシューマン共振は同 時に励起していることより, シューマン共振を発生させている雷放電は単一場所によるものである. (3)異なる周 波数のシューマン共振は同時に励起しているにもかかわらずそれぞれ異なる方位より到来している. (4)通常のシ ユ一マン共振周波数で到来する波は直線偏波に近い伝搬特性で比較的狭い角度で中津川へ到来している. (5)通常 の共振周波数に比べ異なる周波数で到来しているシューマン共振の場合は棈円偏波で，広い角度より到来してい る. (6)通常の共振周波数に比べ異なる周波数で到来しているシューマン共振の場合は雷放電で励起が変化する状 態が観測される場合がある.

これらのことより，9月 15 日に観測された通常のシューマン共振 $(\mathrm{Bx})$ は発生時刻から南アメリカに広く分布す る雷放電を源としその発生場所と中津川を大円とする伝搬経路でのシューマン共振と考えられる [12].よって, その到来方位は中津川から見て雷放電発生の大円方向を指すものと考えられる，そして，通常のシューマン共振 周波数より，大きく異なるシューマン共振は，シューマン共振を生成する雷放電発生場所と中津川とは異なる別 の場所を大円として共振しているものと考えられる.そして，この大円伝搬路の一部に電離層の擾乱が発生して おり，共振の電磁波の一部が中津川方向に反射されたものと考えられる. 電離層の擾乱を発生させている場所が 中津川から $1000 \mathrm{~km}$ オーダの距離にあれば直線偏波に近い伝搬特性を示し，数 $100 \mathrm{~km}$ 程度であれば直線偏波とはな らない，そして，電離層擾乱発生の場所こそが地震前兆の現象を発生させている場所と考えられる.

また，可能性としては地震前兆によるパルス性雑音によりシューマン共振が発生し，パルス性雑音発生場所と 中津川を大円とした伝搬で共振が生成されている可能性もある．しかし、この場合は生成されるシューマン共振 は1つであり、同時に生成される異なる周波数の $\mathrm{Bx}, \mathrm{By}$ は存在しない。よって，中津川で観測されるシューマン 共振で，通常とは異なる周波数の到来方位が地震前兆現象を発生させている震央の方位を示しているものと考え られる. 地震前兆現象として電離層が擾乱し，その地点で観測されるシューマン共振の波を反射させ，中津川方 向に伝搬させたものと考えられる. そして, 最も興味が持たれることはこの励起の 6 日後に中津川より $35^{\circ}$ の方 位にある台湾で $M=7.6$ の地震が発生していることである.

一般に, シューマン共振は概ね $8 \mathrm{~Hz}$ の基本波(Sch1)，14Hz(Sch2)の第 2 高調波, $20 \mathrm{~Hz}(\mathrm{Sch} 3)$ の第 3 高調波， $26 \mathrm{~Hz}$ (Sch4)の第 4 高調波などが観測される.しかし, 通常は基本波が最も強く, 高次の高調波になるにつれ背景 雑音に埋もれ観測することが困難となる $[8]$ 。 また，どの高調波が最も強く受信されるかは雷放電特性（強度の周 波数特性）が同一とすれば発生場所と受信点の距離に依存する。しかし，どの場合であっても他の高調波がほと んど受信されないということは無く, 各高次のシューマン共振の強度は伝搬経路の日変化のため, 一般的には周 期的に変動する。しかし，15 日ファイル0に始まったシューマン共振の励起は 19 日ファイル 3 まで Sch4が最大 強度を継続する.このように, Sch4のみが極端に強く, かつまた長時間にわたり検出された例は 1999 年の 9 月の みである。

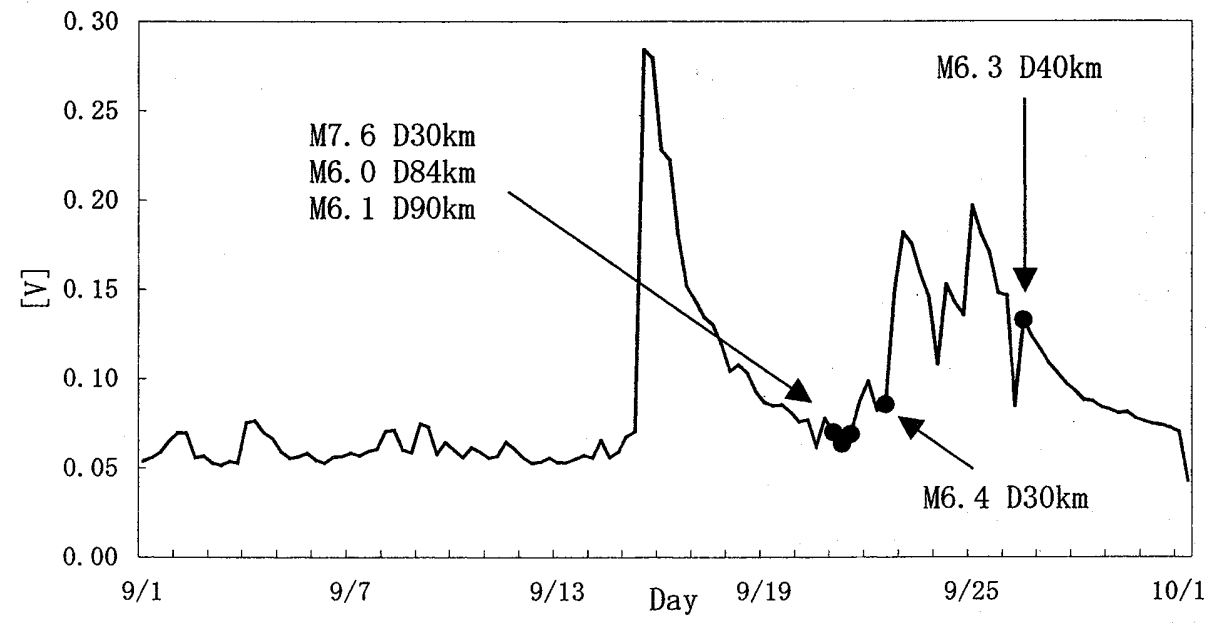

Fig. 9. The drift of the intensity of Sch4 in September. 
1999 年 9 月にお ける Sch4 成分が存在する $20.02 \mathrm{~Hz}$ 34. $96 \mathrm{~Hz}$ 帯域における平均水平磁界強度の変動を図 9 に示 す.明らかに，9月15日から 16 日にかけて極端な強度の上昇と 23 日から 25 日までの緩やかな上昇と下降が見ら れる. 9 月 15 日の上昇では, 6 日後の 9 月 21 日台湾で午前 2 時 48 分に $M=7.6$ の本震, 2 時 57 分に $M=6.0,3$ 時 11 分に $M=6.1$ の余震, また 9 月 22 日 9 時 15 分にも $M=6.4$ の余震が観測されている[5].また, 15 日ほどの強度 は無いが 23 日からの緩やかな上昇は 9 月 21 日の本震およびその他の余震による影響であるか, またはその後に 発生する 26 日 8 時 53 分にM=6.5 の前兆を示しているかは明らかではない.

電離層の擾乱は地磁気擾乱に影響されることは広く知られている.しかし，このシューマン共振の異常励起と は明らかな相関は得られなかった。 よって，9月15 日におけるシューマン共振の励起は台湾で発生した M=7.6の 地震に深く関係があると考えられる．以上の観点から，By のシューマン共振 $25.29 \mathrm{~Hz}$ に強く影響を与えている図 8のパルス性雑音を見直してみよう. シューマン共振を励起するパルス性雑音の到来方位は概ね $35^{\circ}$ で, 中津川 観測地点より台湾方向を示している. かつまた, このパルス雑音は Bx のシューマン共振 $26.37 \mathrm{~Hz}$ の励起にはほと んど影響を与えていない.よって，パルス性雑音が台湾上空で発生していると仮定すれば, By のシューマン共振 25. $29 \mathrm{~Hz}$ は雷放電の波源と台湾とを結ぶ大円上の伝搬路を持つシューマン共振と考えることができる.かつまた， $\mathrm{Bx}$ のシューマン共振 $26.37 \mathrm{~Hz}$ は雷放電の波源と中津川を結ぶ大円上の伝搬路を持つシューマン共振と考えること ができる. 従って, 台湾上空に伝搬路を持つシューマン共振 $25.29 \mathrm{~Hz}$ は電離層擾乱により通常とは大きく異なる 共振周波数を持ち電離層擾乱のため中津川観測所へ反射されたものと考えられる，一方，中津川上空に伝搬路を 持つシューマン共振 $26.37 \mathrm{~Hz}$ は地震による電離層の擾乱を受けていないため，通常のシューマン共振周波数と大 きく異なることはないと考えられる.このように 15 日におけるシューマン共振の励起と Bx, By の周波数のずれは 9 月 23 日から始まる励起でも見られ，台湾での異常伝搬が強く推定される. なお， 1999 年 1 月から 2004 年 8 月 までに発生した $M=5.0$ 以上の地震は 33 回で, 陸上の地震 7 回の内 6 回に, また, 海中の地震 26 回の内マグニチ ュードが大きく陸地に近い 4 回にシューマン共振の前兆現象が見られた.

\section{5.むすび}

科学的な地震予知の研究は学問的のみならず被害を最小に押さえるため極めて重要な社会的課題である. 特に, 短期的な予知の研究は多くの関心を集めている，我々は電磁波を用いた地震予知が有望と考えているが，直接観 測法と間接観測法を両立させることは観測設備, 解析能力に限界がある. そこで ELF 帯電磁波を用いて両立させ る観測法の開発に取り組んでいる.ここでは，1999 年 9 月に発生した台湾地震における ELF 電磁波の直接観測法 とシューマン共振を用いた間接観測法について一例を示した. いずれの観測法であっても地震前兆現象と考えら れる電磁波の励起が観測された。特に，シューマン共振を用いた間接観測法は局電波を用いた間接観測法と比べ 観測地点の電磁雑音環境の設定は限定されるが直接観測法との比較が容易にでき, 有望な観测手法と考えられる.

\section{参考文献}

[1] 0. Molchanov, A. Kulchisky, M. Hayakawa, Inductive seismo-electromagnetic effect in relation to seismogenic ULF emission, Natural Hazards and Earth System Sciences, 1, pp. 61-67, 2001.

[2] M. Hayakawa, O. A. Molchanov, T. Ondoh, E. Kawai, The precursory signature effect of the Kobe earthquake on VLF subionospheric signals, J. Comm. Res. Lab., 43, pp. 413-418, 1996.

[3] K. Ohta, K. Umeda, N. Watanabe, M. Hayakawa, ULF/ELF emissions observed in Japan, possibly associated with the Chi-Chi earthquake in Taiwan, Natural Hazards and Earth System Sciences, 1, pp. 37-42, 2001.

[4] K. Ohta, K. Makita, M. Hayakawa, On the association of anomalies subionospheric VLF propagation at Kasugai with earthquakes in the Tokai area, Japan, J. Atmos. Electr., 20,2, pp. 85-90, 2000.

[5] 地震加速度情報, www. adep. or. jp

[6] 岡田敏美, 森山伸二, 岩井“章:“ホイスラの 2 周波数方位測定装置とその観測結果”, 電子通信学会論文誌, pp. 993-1000, J61-B, 12, 1978.

[7] M. Seto, K. Murayama, Y. Kitamura, T. Watanabe, Observation of seismo-genic ELF magnetic field variations and seismo-electric currents in a power transmission system, Seismo Electromagnetics, Eds. M. Hayakawa and 0.A. Molchanov, pp. 69-75, 2002.

[8] W. 0.Schumann, On the free oscillations of a conducting sphere which is surrounded by an air layer and an ionosphere she11, Z. Naturforschaftung, 7a, pp. 149-154, 1952.

[9] 佐尾和夫, 空電, pp. 106-107, p. 82, 成山堂書店, 1981.

[10] 太田健次, 原 俊介, 早川正士, TT 法による地震前兆現象の検出改善, J. Atmos. Electr., 24, 1, pp. 31-38, 2004.

[11] 太田健次, 花井伸一, 原 俊介, 早川正士, JG2AS 局を用いた地震前兆現象の観測, J. Atmos. E1ectr., 23, 2, pp. 85-95, 2004.

[12] A. P. Nickolaenko, M. Hayakawa, Resonances in the Earth-Ionosphere Cavity, p. 267, Kluwer Academic Publishers, 2002.

(Received November 2, 2004; revised December 25, 2004; accepted January 15, 2005) 